\title{
18. CLAY MINERALS IN MESOZOIC AND CENOZOIC SEDIMENTS OF DEEP SEA DRILLING PROJECT LEG $62^{1}$
}

\author{
M. A. Rateev, P. P. Timofeev, and V. I. Koporulin, \\ Geological Institute of the U.S.S.R. Academy of Sciences, Moscow, U.S.S.R.
}

\section{INTRODUCTION}

The main tasks of this study were (1) identification of minerals of the clay fraction, (2) identification of claymineral associations in relation to stratigraphic intervals, and (3) elucidation of genetic relations of clay minerals with types of sediments and factors of sedimentation. Identification of clay minerals was carried out mainly with an X-ray diffractometer (DRON-I). $\mathrm{X}$-ray diffractograms were prepared by means of $\mathrm{CuK} \alpha$ radiation, at $35 \mathrm{~kW}$ and a current of $20 \mathrm{ma}$. The scanning rate was $2 \% \mathrm{~min}$. Oriented specimens were prepared for the $<1-\mu \mathrm{m}$ fraction (and partly for the $<10$ $\mu \mathrm{m}$ fraction because of insufficient core material) in three states: air-dried, saturated with glycerine, and heated at $550^{\circ} \mathrm{C}$.

\section{STRUCTURAL CHARACTERISTICS OF CLAY MINERALS}

The following minerals were recognized in the clay fraction of sediments penetrated by DSDP Leg 62 holes: illite, chlorite, kaolinite, montmorillonite (smectite); highly expandable (montmorillonite-illite) and slightly expandable (illite-montmorillonite) mixed-layer clays; clinoptilolite and heulandite; quartz, cristobalite, and tridymite; and an admixture of feldspars.

Illite in sediments penetrated during Leg 62 usually shows very sharp peaks $(d / n=10 \AA)$; this attests to its good crystallinity. Insignificant expansion is observed much less frequently. Judging from the (060) dimension, it is dioctahedral.

Kaolinite usually is present as a small admixture. It is identified by standard peaks at 7.15 and $3.57 \AA$, disappearing after heating at $550^{\circ} \mathrm{C}$ and preserved after treatment with $10 \% \mathrm{HCl}$.

Chlorite too is characterized by good crystallinity and is trioctahedral.

Montmorillonite, with peaks at 14.1 to $14.7 \AA$ in an air-dried state, has $\mathrm{Ca}^{2+}$ in its exchange complex. After saturation with glycerine it expands to $17.9 \AA$ (Fig. 1).

Mixed-layer clays include montmorillonite-illite of a disordered structure, similar to montmorillonite with a rather small number of illite layers. It is very difficult in many cases to identify exactly whether we deal with a very fine-grained smectite or with a montmorilloniteillite mineral mixed-layer clay, which is characterized by

\footnotetext{
1 Initial Reports of the Deep Sea Drilling Project, Volume 62.
}

somewhat asymmetrical peaks at $14.7 \AA$ in an air-dried state, and at 18.8 to $19.6 \AA$ after saturation with glycerine.

The second type of disordered slightly expandable mixed-layer mineral (illite-montmorillonite) is identified by Drits and Sakharov (1976) by the peak $d=$ $9.97 \AA$ for a natural sample, and $10 \AA$ for a sample saturated with glycerine or heated at $550^{\circ} \mathrm{C}$.

Clinoptilolite has a distinctive, sharp peak $(d / n=$ $8.8 \AA$ ). Heulandite shows peaks at 8.5 and $5.2 \AA$.

\section{STRATIGRAPHIC DISTRIBUTION OF CLAY MINERALS}

Stratigraphic distribution of clay minerals was studied for three regions: (1) western Mid-Pacific mountains (Site 463); (2) northern Hess Rise (Site 464); (3) southern Hess Rise (Sites 465 and 466).

\section{Site $\mathbf{4 6 3}$}

At Site 463 , relative clay-mineral abundances identify units which generally correspond to lithologic and timerock units (Fig. 2; Table 1.)

The oldest Mesozoic sediments penetrated by Hole 463 (late Barremian; Cores 92-78) are clastic limestones alternating with nannofossil-foraminifer oozes.

The clay fraction is composed of a disordered mixedlayer montmorillonite-illite mineral or fine-grained montmorillonite with a small admixture of illite and silica minerals.

The clay fraction of pelitomorphic limestones of early Aptian age (Cores 77-75) contains a disordered mixed-layer mineral of the montmorillonite-illite type, or fine-grained montmorillonite with an admixture of illite and zeolite.

Beds of partly silicified limestones of early Aptian age with an admixture of volcanic ash of relatively acid (less frequently basic) composition (Cores 74-69) have a clay fraction of a different composition. The clay fraction here has fine-grained, authigenic montmorillonite developed from basic volcanic glass, and a disordered mixed-layer mineral (montmorillonite-illite), close to montmorillonite, developed from volcanic glass of more-acid composition (perhaps andesite-basalt).

Authigenic smectitic minerals are associated with a considerable amount of clinoptilolite. Devitrification of volcanic glass was likely influenced by hydrothermal solutions. Cores 70 and 71 are enriched in organic carbon. Limestones overlying those enriched in organic matter (Cores 68 and 67; of early Aptian age) are 


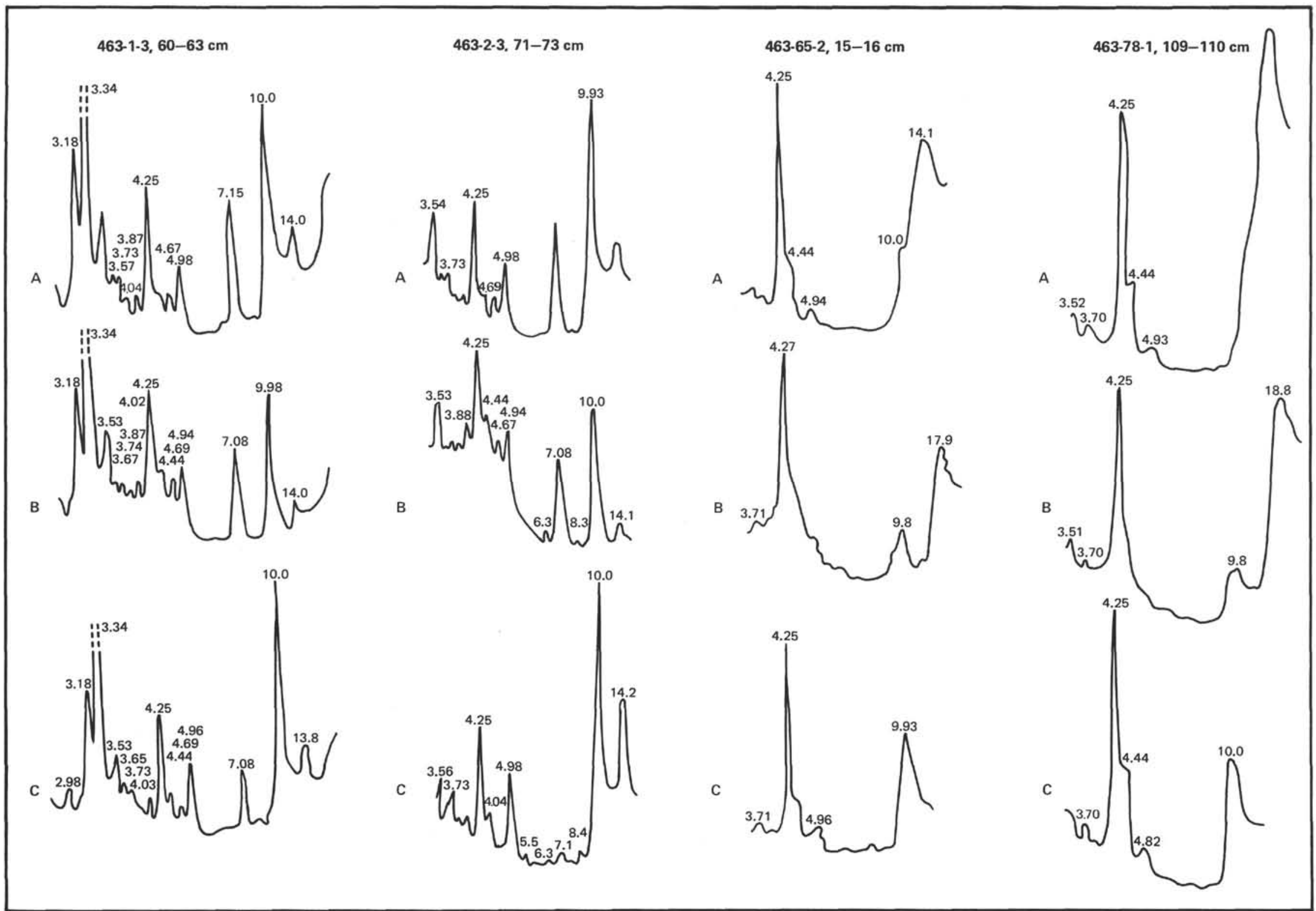

Figure 1. X-ray difractograms of clay minerals in samples from Site 463. A. Natural, air-dried samples. B. Saturated with glycerine. C. Heated at 550 ${ }^{\circ} \mathrm{C}$. The clay fraction in Sample $463-1-2$, $60-62 \mathrm{~cm}$ abounds in illite, with an admixture of chlorite. In Sample 463-2-3,71-73 cm, the clay fraction is composed of a mixed-layer mineral of the (montmorillonite-illite) type, with prevalence of illitic layers. Sample $463-65-2,15-16 \mathrm{~cm}$ is montmorillonitic in the clay fraction. In Sample 463-78-1, 109-110 cm, the clay fraction is composed of a strongly expandable mixed-layer mineral (montmorillonite-illite) with a small amount of illite layers. 
characterized by a predominance of illite and an admixture of montmorillonite in the clay fraction.

Pelitomorphic, thinly laminated limestones of the lower and upper Aptian (Cores 66-60) contain in their clay fraction abundant strongly expandable mixed-layer montmorillonite-illite, similar to smectites with a small admixture of illite.

Early to late Albian pelitomorphic limestones with foraminifers and carbonate detritus (Cores 58-55) are characterized by a predominance of illite in the clay fraction, admixed with a mixed-layer mineral of the montmorillonite-illite type close to smectite.

A thick section of non-laminated foraminifer-nannofossil chalk from the middle Albian to the upper Cenomanian (Cores 52-40) contains practically no clay minerals in the pelitic fraction; which contains only silica minerals.

Foraminifer-nannofossil chalk of the upper Cenomanian to middle Turonian (Cores 39-34) has the same clay minerals as the Albian rocks: abundant illite and a small admixture of considerably expandable mixedlayer montmorillonite-illite close to smectite.

The siliceous middle to upper Turonian rocks (Cores 33-30) contain no clay minerals, only silica minerals, including cristobalite and tridymite.

Non-laminated foraminifer-nannofossil chalk of the Coniacian to upper Turonian (Cores 27-26) differs rather strongly from underlying rocks in the composition of clay minerals of the pelitic fraction, which abounds in illite, with a small admixture of chlorite and an admixture of detrital feldspar and quartz.

Upper Campanian foraminifer-nannofossil chalk (Cores 25-21) have not been analyzed for clay minerals, as we had no core material.

Maastrichtian nannofossil-foraminifer oozes (Cores 20-8) have a clay fraction similar to that of Albian and Turonian deposits, characterized by a predominance of illite and an admixture of a strongly expandable mixedlayer mineral of the montmorillonite-illite type, clinoptilolite, and cristobalite.

Upper Oligocene nannofossil oozes (Cores 6 and 5) have not been analyzed for clay minerals, because of a lack of core material.

Miocene and Pliocene (Cores 3 and 2) and Pleistocene (Core 1) nannofossil-foraminifer oozes have the same composition in the clay fraction: abundant wellcrystallized illite with a varying admixture of chlorite, without expandable phases. These minerals are associated with a constant complex of detrital minerals: feldspar, quartz, less frequently cristobalite.

\section{Site 464}

The clay fraction of Aptian to Cenomanian rocks of Lithologic Unit III (Cores 33-11) has not been studied, because of silicification.

Upper Cretaceous to lower Miocene rocks of Lithologic Unit II (Cores 10-6) are brown clays; the clay fraction (Table 2) is characterized by a predominance of a considerably expandable mixed-layer mineral of the montmorillonite-illite type, with a small proportion of illite layers. In addition, there is a small admixture of detrital illite, chlorite, tridymite, and heulandite.
Upper Miocene to upper Pliocene rocks of Lithologic Unit I (Cores 5-2) are subdivided into Sub-units IB and IA. Sub-unit IB is siliceous clay, whereas Subunit IA is clayey radiolarian ooze. The clay fraction is identical in all samples of Lithologic Unit I, characterized by a polymineralic association with an abundance of detrital minerals: illite, chlorite, and an admixture of strongly expandable mixed-layer montmorillonite-illite type. This distinguishes clays and oozes of Lithologic Unit I from rocks of the underlying unit.

\section{Site $\mathbf{4 6 5}$}

The distribution of clay minerals at Site 465 is shown in Table 3.

The uppermost parts of Lithologic Unit III (Cores $465 \mathrm{~A}-41$ and $465 \mathrm{~A}-40$ ) represent a breccia in which some altered fragments of trachyte are cemented by calcite, dolomite, and barite. The clay fraction is composed of aluminous montmorillonite, formed from trachyte fragments, with a small admixture of illite or mixed-layer montmorillonite-illite and illite-montmorillonite. The montmorillonite-illite contains as much as $20 \%$ illite layers; the illite-montmorillonite contains 15 to $20 \%$ of expandable montmorillonite layers. Some interbeds contain heulandite.

Lithologic Unit II (Cores 465A-39 to 465-26) is composed of laminated limestones of the upper Albian to lower Cenomanian. Thin interbeds of finely crystalline limestones alternate with olive-gray limestones. Cherts are observed throughout Lithologic Unit II. The clay fraction abounds in montmorillonite with organic carbon in the interlayer spaces, and there is a small admixture of poorly crystallized illite and chlorite.

Lithologic Unit I (up to Cores 11-8 and 465A-25 to $465 \mathrm{~A}-4$ ) consists of foraminifer-nannofossil ooze of the lower Maastrichtian, with appreciable pyritization in some intervals. The clay fraction of the lower part of Lithologic Unit I (mostly foraminifer-nannofossil ooze) is mostly smectite, with an insignificant admixture of detrital illite or chlorite. Smectite is represented either by an unstable variety of $\mathrm{Fe}$-montmorillonite or by $\mathrm{Al}-\mathrm{Fe}$-montmorillonite with traces of chloritization. Heulandite is present in places.

The upper part of Lithologic Unit I (mainly nannofossil ooze of the Paleocene to Pleistocene) differs sharply from the underlying deposits in the polymineralic association of the clay fraction, with abundant detrital minerals: illite, chlorite, a small admixture of smectite, quartz, and feldspars.

\section{Site $\mathbf{4 6 6}$}

Site 466 is on southern Hess Rise, approximately 50 $\mathrm{km}$ northwest of Site 465 , in a depression 12 to $16 \mathrm{~km}$ wide and 500 to 550 meters deep, recognized from seismic data. Distribution of clay minerals and their associations at Site 466 is shown in Table 4.

Lithologic Unit II (Cores 35-28; upper Albian to Coniacian) is composed of nannofossil chalk and limestone appreciably enriched in organic matter. The clay fraction is composed of $\mathrm{Fe}$-montmorillonite with indications of chloritization (substitution of aluminum for iron in octahedral layers), and opal-CT. In addition, 
SITE 463

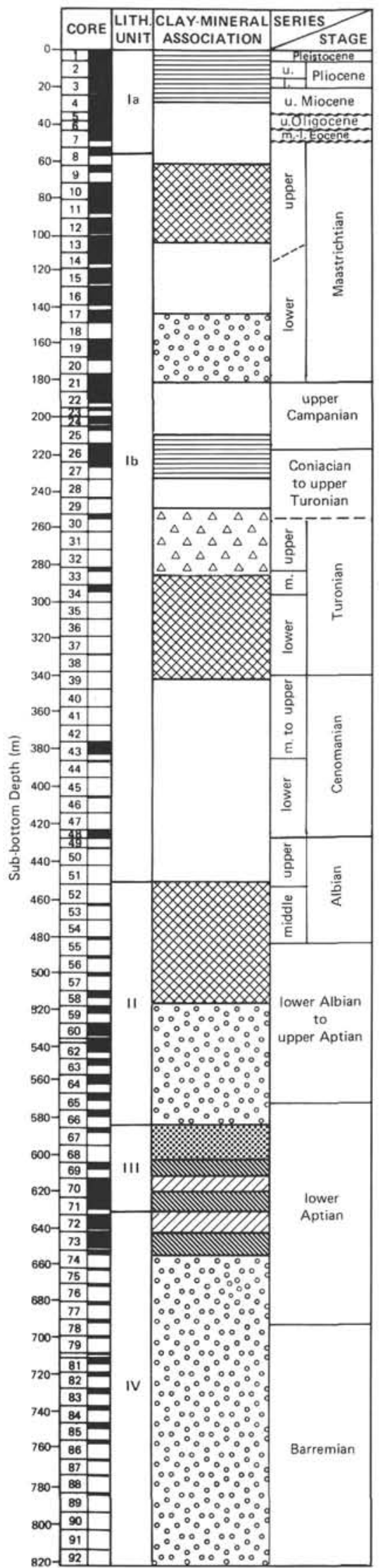

SITE 464

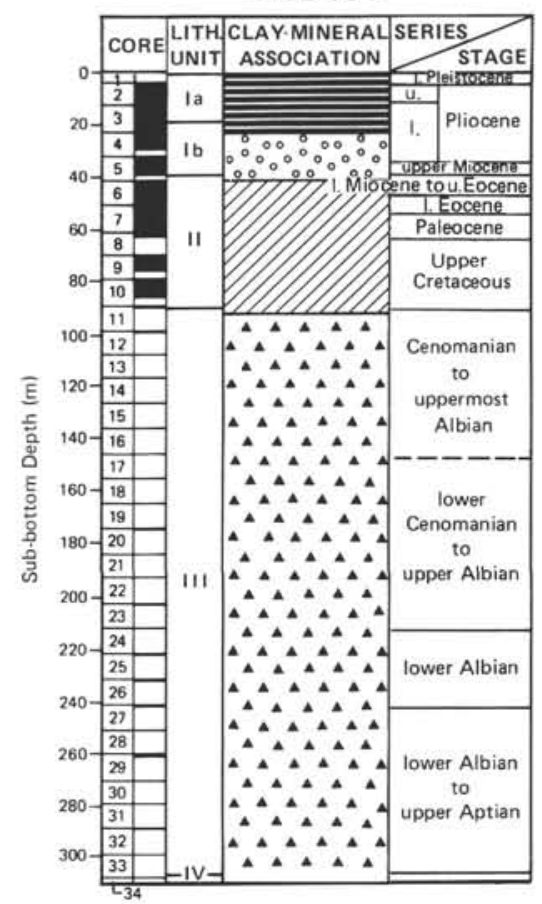

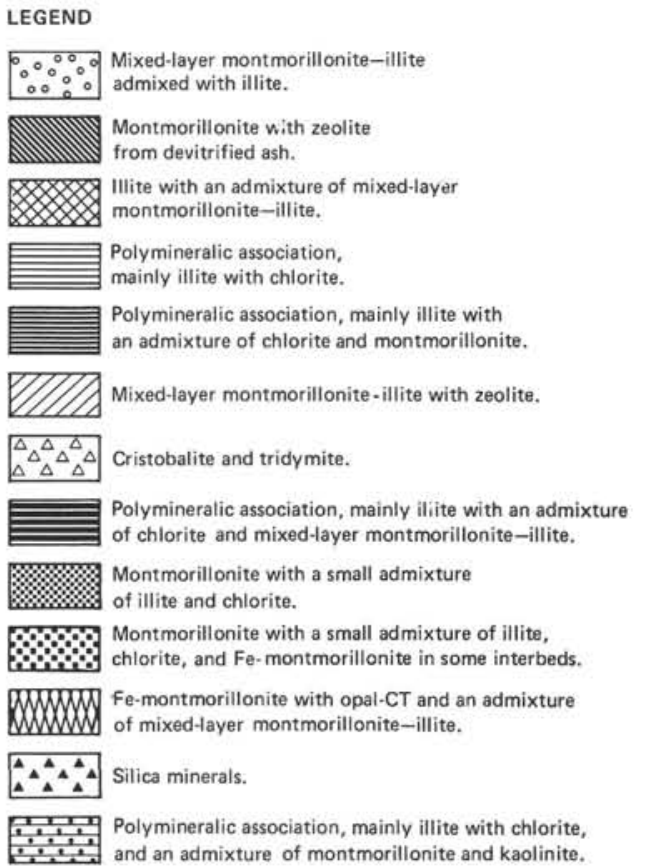

Figure 2. Clay-mineral associations in relation to stratigraphy. 


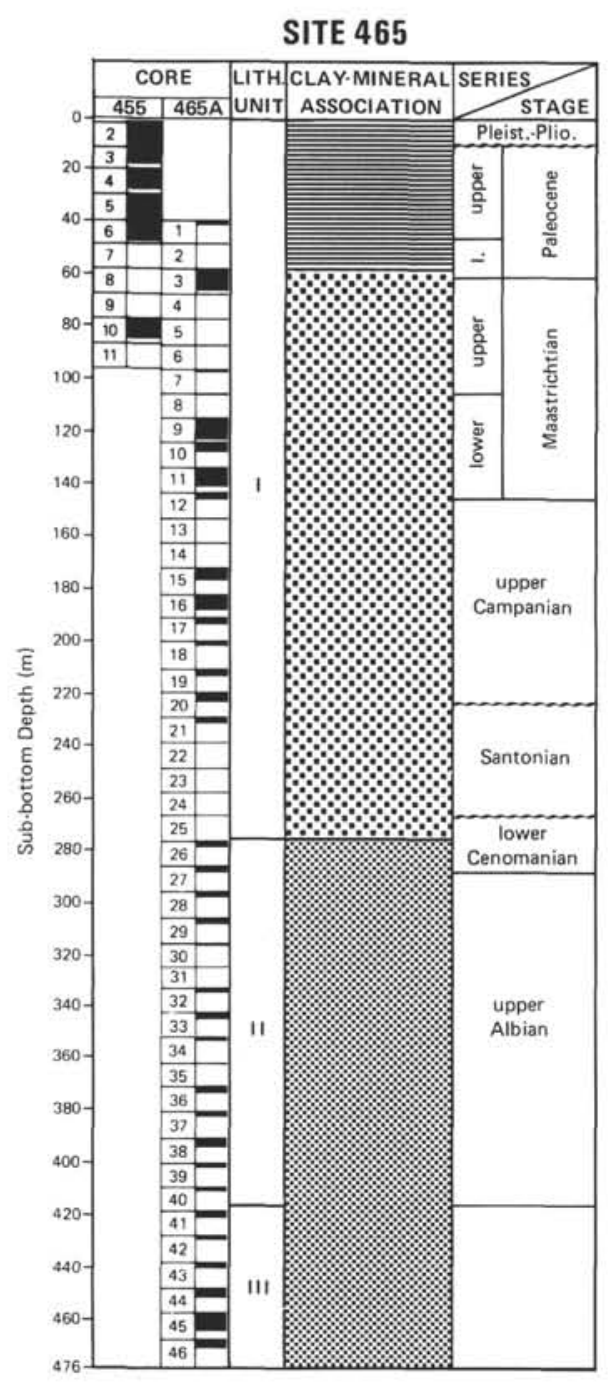

Figure 2. (Continued).

there is an admixture of mixed-layer illite-montmorillonite with varying proportions of the different layers.

The clay fraction of pyrite-bearing clays at the top of Lithologic Unit II abounds in opal-CT, and in Fe-montmorillonite, with an appreciable admixture of mixed -layer illite-montmorillonite with 15 to $20 \%$ expandable layers.

Sub-unit IB from Core 27 to Core 16 (Turonianlower Santonian) is composed of foraminifer-nannofossil ooze with an abundance of siliceous fragments. The clay fraction consists entirely of silica minerals. Sub-unit IIA from Core 15 to Core 10 (upper Campanian-lower Maastrichtian) is represented by foraminifer-nannofossil ooze with a high content of redeposited material, including fragments of cherts, diabases, Inoceramus. The clay fraction is composed mostly of strongly expandable mixed-layer montmorillonite-illite with 20 to $30 \%$ illite layers. In addition, there is a small admixture of illite, zeolite, and quartz.

Sub-unit IA from Core 9 to Core 7 (upper Eocenelow Pliocene) is composed of nannofossil or foraminifer-nannofossil ooze with a great amount of redeposited

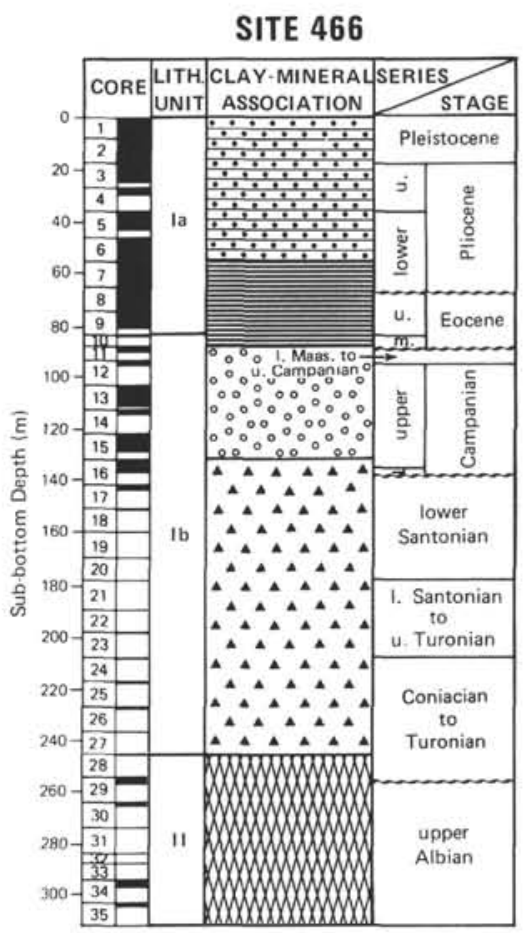

material. The lower part contains chert fragments. The clay fraction is a polymineralic association and differs considerably from that of the underlying beds. It contains an abundance of detrital illite, chlorite, an admixture of montmorillonite (with organic carbon in interlayer spaces), and an appreciable admixture of quartz and feldspars.

Subunit 1A from Core 6 to Core 1 (lower PliocenePleistocene) is composed of foraminifer-nannofossil ooze with radiolarian remains. The clay fraction like that of underlying beds is polymineralic, with an abundance of illite, chlorite, and an admixture of montmorillonite, quartz, and feldspar. It differs in a constant and appreciable admixture of kaolinite that is missing in the underlying beds.

\section{GENETIC TYPES OF CLAY}

Microscopic study of clay- and ash-bearing rocks and insoluble residues of carbonate deposits from Leg 62 sites enables us to single out some genetic types of clay.

1) Diagenetic fine-grained montmorillonite derived from ash and constantly associated with clinoptilolite or 
Table 1. Clay-mineral associations at Site 463.

\begin{tabular}{|c|c|c|c|}
\hline Series/Stage & $\begin{array}{c}\text { Sample } \\
\text { (interval in } \mathrm{cm} \text { ) }\end{array}$ & Clay Minerals of the $<1-\mu \mathrm{m}$ Fraction & General Clay-Mineral Association \\
\hline Pleistocene & $463-1-3,60-62$ & Wlite, chlorite, cristobalite, admixture of quartz and feldspars & \multirow{3}{*}{$\begin{array}{l}\text { Polymineralic association, mainly } \\
\text { illite with chlorite }\end{array}$} \\
\hline Upper Pliocene & $2-3,71-73$ & Wlite, chlorite, cristobalite, admixture of quartz and feldspars & \\
\hline Lower Pliocene & $3-3,72-74$ & Illite, chlorite, cristobalite, admixture of quartz and feldspars & \\
\hline Maastrichtian & $\begin{array}{l}12-6,88-90 \\
17-1,70-72\end{array}$ & $\begin{array}{l}\text { Mlite, mixed-layer montmorillonite-illite, admixture of } \\
\text { clinoptilolite, cristobalite, and quartz. } \\
\text { Mixed-layer montmorillonite-illite, admixture of illite, } \\
\text { tridymite, cristobalite, and quartz. }\end{array}$ & $\begin{array}{l}\text { Illite with an admixture of mixed- } \\
\text { layer montmorillonite-illite }\end{array}$ \\
\hline $\begin{array}{l}\text { Turonian } \\
\text { to } \\
\text { Coniacian }\end{array}$ & $\begin{array}{l}26, \mathrm{CC} \\
31-1,6-7\end{array}$ & $\begin{array}{l}\text { Illite, chlorite, admixture of quartz and feldspar } \\
\text { Cristobalite, tridymite, quartz }\end{array}$ & $\begin{array}{l}\text { Polymineralic association, mainly } \\
\text { illite with an admixture of chlorite } \\
\text { Cristobalite and tridymite }\end{array}$ \\
\hline $\begin{array}{l}\text { Lower } \\
\text { Turonian }\end{array}$ & $38-1,13-14$ & $\begin{array}{l}\text { Illite, small admixture of mixed-layer montmorillonite-illite, } \\
\text { quartz, and feldspars }\end{array}$ & \multirow[t]{2}{*}{$\begin{array}{l}\text { Illite with an admixture of mixed- } \\
\text { layer montmorillonite-illite }\end{array}$} \\
\hline \multirow[t]{2}{*}{$\begin{array}{l}\text { Lower Albian } \\
\text { to } \\
\text { Upper Aptian }\end{array}$} & $\begin{array}{l}58-2,98-99 \\
59-1,6-7\end{array}$ & $\begin{array}{l}\text { Illite, admixture of mixed-layer montmorillonite-illite and } \\
\text { quartz } \\
\text { Mixed-layer montmorillonite-illite, admixture of quartz and } \\
\text { feldspar }\end{array}$ & \\
\hline & $62-2,26-27$ & $\begin{array}{l}\text { Mixed-layer montmorillonite-illite, admixture of quartz and } \\
\text { feldspar }\end{array}$ & \multirow[t]{2}{*}{$\begin{array}{l}\text { Mixed-layer montmorillonite-illite } \\
\text { with an admixture of illite }\end{array}$} \\
\hline \multirow[t]{3}{*}{ Lower Aptian } & $\begin{array}{l}65-2,15-16 \\
65-2,28-29\end{array}$ & $\begin{array}{l}\text { Mixed-layer montmorillonite-illite admixture of illite } \\
\text { and quartz } \\
\text { Mixed-layer montmorillonite-illite, admixture of illite, } \\
\text { chlorite, and quartz }\end{array}$ & \\
\hline & $67-2,0-3$ & Illite, montmorillonite, admixture of quartz and feldspars & Illite with montmorillonite \\
\hline & $\begin{array}{l}69, \mathrm{CC}, 8-9 \\
70-1,50-51 \\
70-3,61-62 \\
70-5,106-107 \\
70-6,42-43 \\
70-7,26-27 \\
71-1,15-16 \\
71-1,95-97 \\
71-2,68-69 \\
74-1,15-16 \\
74-1,70-71 \\
78-1,109-110 \\
\end{array}$ & $\begin{array}{l}\text { Mixed-layer montmorillonite-illite, admixture of clinoptilolite } \\
\text { Mixed-layer montmorillonite-illite, admixture of clinoptilolite } \\
\text { Mixed-layer montmorillonite-illite, admixture of clinoptilolite } \\
\text { Mixed-layer montmorillonite-illite, admixture of clinoptilolite } \\
\text { Mixed-layer montmorillonite-illite, admixture of clinoptilolite } \\
\text { Mixed-layer montmorillonite-illite, admixture of clinoptilolite } \\
\text { Montmorillonite, admixture of clinoptilolite } \\
\text { Mixed-layer montmorillonite, admixture of illite and } \\
\text { silica minerals } \\
\text { Mixed-layer montmorillonite, admixture of illite and } \\
\text { silica minerals } \\
\text { Mixed-layer montmorillonite-illite with clinoptilolite } \\
\text { Mixed-layer montmorillonite-illite with clinoptilolite } \\
\text { Mixed-layer montmorillonite-illite, small admixture of illite }\end{array}$ & $\begin{array}{l}\text { Alternation of smectite or mixed- } \\
\text { layer montmorillonite-illite with } \\
\text { abundant zeolite }\end{array}$ \\
\hline $\begin{array}{l}\text { Upper } \\
\text { Barremian }\end{array}$ & $\begin{array}{l}81-1,25-26 \\
82-1,40-41 \\
83-1,45-47 \\
84-1,123-124 \\
85-1,128-130 \\
88-1,33-35 \\
89-1,110-111\end{array}$ & $\begin{array}{l}\text { Mixed-layer montmorillonite-illite, small admixture of illite } \\
\text { Mixed-layer montmorillonite-illite, small admixture of illite } \\
\text { Mixed-layer montmorillonite-illite, small admixture of illite } \\
\text { Silica minerals } \\
\text { Mixed-layer montmorillonite-illite, small admixture of smectite } \\
\text { Mixed-layer montmorillonite-illite, small admixture of smectite } \\
\text { Silica minerals }\end{array}$ & $\begin{array}{l}\text { Mixed-layer montmorillonite-illite } \\
\text { with an admixture of illite }\end{array}$ \\
\hline
\end{tabular}

Table 2. Clay-mineral associations at Site 464.

\begin{tabular}{|c|c|c|c|}
\hline Series/Stage & $\begin{array}{l}\text { Sample } \\
\text { (interval in } \mathrm{cm} \text { ) }\end{array}$ & Clay Minerals of the $<1-\mu \mathrm{m}$ Fraction & General Clay-Mineral Association \\
\hline Upper Pliocene & $\begin{array}{c}464-2-2,104-108 \\
2-3,71-73 \\
2-4,44-48\end{array}$ & $\begin{array}{l}\text { Illite, mixed-layer montmorillonite-illite, chlorite, admixture of } \\
\text { cristobalite, tridymite, quartz, and feldspars } \\
\text { Illite, chlorite, admixture of cristobalite, opal-CT, quartz, } \\
\text { and feldspars } \\
\text { Illite, admixture of montmorillonite and chlorite }\end{array}$ & \multirow[t]{3}{*}{$\begin{array}{l}\text { Polymineralic association, mainly } \\
\text { illite with chlorite and mixed-layer } \\
\text { clay }\end{array}$} \\
\hline Lower Pliocene & $\begin{array}{l}3-3,80-84 \\
4-2,52-55\end{array}$ & $\begin{array}{l}\text { Illite, mixed-layer montmorillonite-illite, traces of illite and chlorite } \\
\text { Illite, mixed-layer montmorillonite-ilite, chlorite, admixture of } \\
\text { cristobalite, tridymite, quartz, and feldspars }\end{array}$ & \\
\hline $\begin{array}{l}\text { Upper Miocene } \\
\text { to }\end{array}$ & $5-4,107-111$ & $\begin{array}{l}\text { Illite, mixed-layer montmorillonite-illite, chlorite, traces } \\
\text { of quartz and feldspars }\end{array}$ & \\
\hline Upper Cretaceous & $\begin{array}{l}6-4,94-96 \\
7-4,120-122 \\
8-2,21-23 \\
8-2,31-33 \\
9-1,123-125 \\
9-5,30-32 \\
10-2,120-122 \\
10-2,64-67\end{array}$ & $\begin{array}{l}\text { Mixed-layer montmorillonite-illite, illite, and chlorite } \\
\text { Mixed-layer montmorillonite-illite, illite, and chlorite } \\
\text { Mixed-layer montmorillonite-illite, illite, and chlorite } \\
\text { Smectite, small admixture of illite and chlorite , quartz and feldspars } \\
\text { Smectite } \\
\text { Smectite, small admixture of illite, heulandite, amorphous silica } \\
\text { Mixed-layer montmorillonite-illite, admixture of zeolite } \\
\text { Mixed-layer montmorillonite-illite, admixture of zeolite } \\
\text { and tridymite }\end{array}$ & $\begin{array}{l}\text { Mixed-layer montmorillonite-illite, } \\
\text { small admixture of illite, chlorite, } \\
\text { and zeolite }\end{array}$ \\
\hline
\end{tabular}

heulandite with no detrital minerals. It is characterized by authigenic globules and nodules, as well as by replacement of fragments of ash and organic remains. We assume that this type of smectite develops by decomposition of unstable volcanic glass of basaltic composition.

2) Strongly expandable mixed-layer montmorillonite-illite, similar to smectite. This likely has developed after volcanic glass too, but glass of more-acid composi- tion. It contains a small proportion of illite layers. The dependence of clay formation on the chemistry of the volcanogenic rocks is verified by the data of DSDP Legs $62,63,65$, and others, which dealt with fine-grained volcanogenic material.

3) A slightly expandable mixed-layer illite-montmorillonite. We believe that formation of this mineral is related to degradation of illite and, especially, easily de- 
Table 3. Clay-mineral associations at Site 465.

\begin{tabular}{|c|c|c|c|}
\hline Series/Stage & $\begin{array}{l}\text { Samples } \\
\text { (interval in cm) }\end{array}$ & Clay Minerals of the $<10-\mu \mathrm{m}$ Fraction & General Clay-Mineral Association \\
\hline Pleistocene & $\begin{array}{r}465-1-1,38-40 \\
1-1,51-53 \\
1-2,38-40\end{array}$ & $\begin{array}{l}\text { Illite, chlorite, small admixture of montmorillonite, quartz, and feldspars } \\
\text { Illite, chlorite, small admixture of montmorillonite, quartz, and feldspars } \\
\text { Illite, chlorite, small admixture of montmorillonite, quartz, and feldspars }\end{array}$ & \multirow[t]{2}{*}{$\begin{array}{l}\text { Polymineralic association, mainly } \\
\text { illite, with chlorite and an } \\
\text { admixture of smectite }\end{array}$} \\
\hline Pliocene & $2-1,27-29$ & Illite, chlorite, small admixture of montmorillonite, quartz, and feldspars & \\
\hline $\begin{array}{l}\text { Lower } \\
\text { Paleocene }\end{array}$ & $465 \mathrm{~A}-3-1,118-120$ & $\begin{array}{l}\text { Montmorillonite, small admixture of illite, traces of chlorite } \\
\text { and clinoptilolite }\end{array}$ & $\begin{array}{l}\text { Montmorillonite, small admixture } \\
\text { of illite and chlorite }\end{array}$ \\
\hline $\begin{array}{l}\text { Lower } \\
\text { Maastrichtian }\end{array}$ & $11-2,65-69$ & $\begin{array}{l}\text { Fe-montmorillonite (with indications of chloritization), small admixture of } \\
\text { chlorite and heulandite }\end{array}$ & \multirow{2}{*}{$\begin{array}{l}\text { Montmorillonite, small admixture } \\
\text { of illite, chlorite, and } \mathrm{Fe}- \\
\text { montmorillonite in some interbeds }\end{array}$} \\
\hline $\begin{array}{l}\text { Upper } \\
\text { Campanian }\end{array}$ & $17-1,130-132$ & $\begin{array}{l}\text { Fe-montmorillonite (with organic carbon in interlayer spaces), small } \\
\text { admixture of illite, zeolite, and opal }\end{array}$ & \\
\hline \multirow[t]{2}{*}{$\begin{array}{l}\text { Upper } \\
\text { Albian }\end{array}$} & $\begin{array}{l}29-1,36-38 \\
33-2,50-53\end{array}$ & $\begin{array}{l}\text { Al-montmorillonite, small admixture of mixed-layer montmorillonite-illite } \\
\text { with } 15-20 \% \text { smectite layers, traces of chlorite } \\
\text { Mixed-layer montmorillonite-illite, small admixture of illite, smectite, } \\
\text { abundant amorphous silica }\end{array}$ & $\begin{array}{l}\text { Montmorillonite, small admixture } \\
\text { of illite or chlorite }\end{array}$ \\
\hline & $\begin{array}{l}40-1,137-138 \\
40-2,7-8 \\
40-2,7-8 \\
40-2,52-54\end{array}$ & $\begin{array}{l}\text { Al-montmorillonite, small admixture of illite and heulandite } \\
<10-\mu \mathrm{m} \text { : mixed-layer montmorillonite-illite with } 30-40 \% \text { illite layers, } \\
\text { small admixture of feldspars } \\
<1-\mu \mathrm{m} \text { : Al-Fe-montmorillonite (small proportion of illite layers), } \\
\text { admixture of mixed-layer montmorillonite-illite (15-20\% smectite layers) } \\
<1-\mu \mathrm{m} \text { : Al-montmorillonite (small proportion of illite layers), admixture } \\
\text { of mixed-layer montmorillonite-illite (15-20\% smectite layers) }\end{array}$ & $\begin{array}{l}\text { Montmorillonite, admixture of } \\
\text { mixed-layer montmorillonite- } \\
\text { illite and illite-montmorillonite }\end{array}$ \\
\hline
\end{tabular}

Table 4. Clay-mineral associations at Site 466.

\begin{tabular}{|c|c|c|c|}
\hline Series/Stage & $\begin{array}{l}\text { Sample } \\
\text { (interval in } \mathrm{cm} \text { ) }\end{array}$ & Clay Minerals of the $<10-\mu \mathrm{m}$ Fraction & Clay-Mineral Association \\
\hline Pleistocene & $466-1-4,27-29$ & $\begin{array}{l}\text { Illite, chlorite, admixture of montmorillonite, } \\
\text { small admixture of mixed-layer mont- } \\
\text { morillonite-illite, kaolinite, quartz, and } \\
\text { and feldspars } \\
\text { Illite, chlorite, admixture of montmorillonite, } \\
\text { kaolinite, quartz, and feldspars }\end{array}$ & \multirow[t]{3}{*}{$\begin{array}{l}\text { Polymineralic association with abundant detrital } \\
\text { illite and chlorite, and an admixture of smectite } \\
\text { and kaolinite }\end{array}$} \\
\hline $\begin{array}{l}\text { Upper } \\
\text { Pliocene }\end{array}$ & $\begin{array}{l}3-1,20-22 \\
3-3,8-10 \\
4-1,120-122\end{array}$ & $\begin{array}{l}\text { Illite, chlorite, admixture of montmorillonite, } \\
\text { kaolinite, heulandite group, quartz, and } \\
\text { feldspars } \\
\text { Ilite, chlorite, admixture of montmorillonite, } \\
\text { kaolinite, quartz, and feldspars } \\
\text { Illite, chlorite, admixture of montmorillonite, } \\
\text { kaolinite, quartz, mixed-layer montmoril- } \\
\text { lonite-illite, and feldspars }\end{array}$ & \\
\hline $\begin{array}{l}\text { Lower } \\
\text { Pliocene }\end{array}$ & $\begin{array}{l}5-2,91-93 \\
6-5,65-67 \\
7-6,60-62\end{array}$ & $\begin{array}{l}\text { Illite, chlorite, admixture of montmorillonite, } \\
\text { kaolinite, quartz, mixed-layer montmorillon- } \\
\text { ite-illite, and feldspars } \\
\text { Illite, chlorite, admixture of montmorillonite, } \\
\text { kaolinite, quartz, mixed-layer montmoril- } \\
\text { lonite-illite, and feldspars } \\
\text { Illite, chlorite, admixture of montmorillonite }\end{array}$ & \\
\hline $\begin{array}{l}\text { Upper } \\
\text { Eocene }\end{array}$ & $\begin{array}{l}8-3,2-4 \\
9-3,10-12\end{array}$ & $\begin{array}{l}\text { Illite, chlorite, admixture of montmorillonite } \\
\text { Illite, chlorite, admixture of montmorillonite }\end{array}$ & $\begin{array}{l}\text { Polymineralic association, mainly illite and } \\
\text { chlorite, with an admixture of smectite }\end{array}$ \\
\hline $\begin{array}{l}\text { Lower } \\
\text { Maastrichtian } \\
\text { to Upper } \\
\text { Campanian } \\
\end{array}$ & $11-1,27-29$ & $\begin{array}{l}\text { Mixed-layer montmorillonite-illite with } \\
20-30 \% \text { illite layers, small admixture of } \\
\text { illite, zeolite, feldspars, and quartz }\end{array}$ & $\begin{array}{l}\text { Mixed-layer clays, with an admixture of illite and } \\
\text { zeolite }\end{array}$ \\
\hline $\begin{array}{l}\text { Coniacian to } \\
\text { Turonian }\end{array}$ & $28, \mathrm{CC}, 20-22$ & $\begin{array}{l}\text { Opal-CT, Fe-montmorillonite, small } \\
\text { admixture of mixed-layer montmorillonite- } \\
\text { illite with } 15-20 \% \text { expandable layers }\end{array}$ & $\begin{array}{l}\text { Opal and smectite with an admixture of mixed- } \\
\text { layer montmorillonite-illite }\end{array}$ \\
\hline $\begin{array}{l}\text { Upper } \\
\text { Albian }\end{array}$ & $\begin{array}{l}29-1,99-100 \\
34-1,106-107\end{array}$ & $\begin{array}{l}\text { Fe-montmorillonite (with indications of } \\
\text { chloritization) admixture of mixed-layer } \\
\text { montmorillonite-illite } \\
\text { Fe-montmorillonite, admixture of mixed-layer } \\
\text { montmorillonite-illite and opal-CT }\end{array}$ & $\begin{array}{l}\text { Fe-montmorillonite with mixed-layer mont- } \\
\text { morillonite-illite and opal-CT }\end{array}$ \\
\hline
\end{tabular}


composed trioctahedral micas of the biotite type. This process appears to occur during transportation of finegrained particles, which can be carried by deep-sea currents over great distances.

4) A widely distributed polymineralic association of clay minerals, identified in Paleocene-Pliocene-Quaternary deep-sea oceanic sediments at most of the studied sites. This association comprises an abundance of detrital illite, chlorite, and smectite, and less frequently kaolinite (Site 466). This testifies to sharply intensified erosion and mechanical denudation, as well as to greater dispersion of terrigenous clays during the Quaternary. These processess were possibly a result of drastic changes in the world ocean level and shore lines and variations of climate.

\section{CONCLUSION}

An older Mesozoic complex of clays at all the sites is characterized by a predominance of smectitic minerals in the clay fraction-true montmorillonite, or similar expandable mixed-layer montmorillonite-illite.

A younger Cenozoic complex is characterized everywhere by a pronounced polymineralic composition of the clay fraction, which abounds in illite and chlorite, less frequently kaolinite, and with a subordinate amount of a smectite.

Study of the lateral distribution of clay minerals and their associations revealed development of mostly mixed-layer montmorillonite-illite in the western MidPacific mountains (Site 463), and in the northern part of Hess Rise (Site 464), as well as wider distribution of true smectites in the southern part of Hess Rise (Sites 465 and 466).

Such a distribution of clay minerals was controlled by the sedimentary environment existing during the MesoCenozoic time in these regions.

As shown by Timofeev et al. (this volume), sedimentation on Hess Rise at the end of the Mesozoic was developing against a background of transgression and changing sedimentation conditions-from shallow water to deep water. There were shoals and islands due to an uneven surface of the ocean bottom; they were composed of igneous rocks varying from tholeiitic basalts to trachytes. Islands and shoals were prominent during Albian to Cenomanian time. Later their numbers decreased, but they existed up to the end of the Mesozoic, as evidenced by remains of redeposited shallowwater mollusks.

Over vast areas of the Pacific Ocean, including those far north of the equator, the climate at the end of the Mesozoic and the beginning of the Cenozoic was equable (Douglas and Savin, 1971, 1974), which favored intense weathering. This led to the supply of cun- siderable amounts of smectite-the most characteristic product of subaerial weathering and subaqueous decomposition of igneous rocks of intermediate and basic composition.

The differences in composition of smectite present in the sediments may reflect variations of composition of the initial rocks and the character of their decomposition. Late Mesozoic time in the Pacific Ocean was characterized by a weakened circulation of water masses, and an absence of (or weak) cold bottom currents from the Arctic areas in particular (Douglas and Savin, 1974; Fisher and Arthur, 1977). This, as well as uneven underwater relief, considerably decreased the supply of clays of different compositions from other regions.

By the end of the Mesozoic, conditions of deep-water oceanic sedimentation were established at Hess Rise. By that time a thick complex of sedimentary rocks had accumulated. It covered the basaltic basement and leveled the relief, so local sources of clays that previously controlled the supply of large amounts of montmorillonite into sediments disappeared. Deep-water sedimentation and leveling of the underwater relief apparently led to incorporation of Hess Rise into a system of currents embracing the central and northern parts of the Pacific Ocean. This provided for the supply of compositionally variable polymineralic clay associations. This was also favored by changes of climate. In the Cenozoic, beginning approximately in the Eocene, considerable differentiation of climate of the Earth took place: cooling in the northern and southern high latitudes, extensive glaciations on land.

At that time higher gradients of temperature were established in the oceans, both vertically and horizontally. Intense circulation of water was established, with strong currents, including cold bottom flows from the polar areas. Intense circulation in the atmosphere was established as well (Fisher and Arthur, 1977).

All this contributed to the distribution of polymineralic and heterogenous clay associations into the ocean from surrounding areas of the land, over great distances.

\section{REFERENCES}

Douglas, R. G., and Savin, S. M., 1971. Isotopic analysis of planktonic foraminifera from the Cenozoic of the Northwest Pacific, Leg 6. In Fischer, A. G., Heezen, B. C., et al., Init. Repts. DSDP, 6: Washington (U.S. Govt. Printing Office), 1130-1223. 1974. Oxygen and carbon isotope analysis of Cretaceous and Tertiary foraminifera from the central North Pacific. In Winterer, E. L., Ewing, J. I., et al., Init. Repts. DSDP, 17: Washington (U.S. Govt. Printing Office), 591-606.

Fischer, A. G., and Arthur, M. A., 1977. Secular variations of ? in the pelagic realm. In Cook, H. E., and Enos, P. (Eds.), Deep Water Carbonate Environments: Soc. Econ. Paleont. Mineral. Publ., 25:19-50. 